\title{
INSIGHTS INTO PREVENTIVE MEASURES FOR DENTAL EROSION
}

\author{
Ana Carolina MAGALHÃES ${ }^{1}$, Annette WIEGAND ${ }^{2}$, Daniela RIOS ${ }^{3}$, \\ Heitor Marques HONÓRIO ${ }^{4}$, Marília Afonso Rabelo BUZALAF ${ }^{5}$
}

1- DDS, MS, PhD, Assistant Professor, Department of Biological Sciences, Bauru School of Dentistry, University of São Paulo, São Paulo, Brazil.

2- Dr Med Dent, Senior Lecturer Clinic for Preventive Dentistry, Periodontology and Cariology, University of Zurich, Switzerland.

3- DDS, MS, PhD, Assistant Professor, Department of Pediatric Dentistry, Orthodontics and Community Health, Bauru School of Dentistry, University of São Paulo, Bauru, SP, Brazil.

4- DDS, MS, PhD, Associate Professor, Department of Pediatric Dentistry, Federal University of Alfenas, Alfenas, MG, Brazil.

5- DDS, MS, PhD, Full Professor, Department of Biological Sciences, Bauru School of Dentistry, University of São Paulo, Bauru, SP, Brazil.

Corresponding address: Ana Carolina Magalhães - Departmento de Ciências Biológicas - FOB/USP - Bauru - SP - Al. Octávio Pinheiro Brisolla, 9-75 - 17012-901 - Bauru - SP - Brasil - Phone +55-14-3235-8246 - Fax: +55-14-3234-3164 - e-mail: acm@usp.br

Received: March 12, 2008 - Modification: May 15, 2008 - Accepted: September 16, 2008

\begin{abstract}
D

ental erosion is defined as the loss of tooth substance by acid exposure not involving bacteria. The etiology of erosion is related to different behavioral, biological and chemical factors. Based on an overview of the current literature, this paper presents a summary of the preventive strategies relevant for patients suffering from dental erosion. Behavioral factors, such as special drinking habits, unhealthy lifestyle factors or occupational acid exposure, might modify the extent of dental erosion. Thus, preventive strategies have to include measures to reduce the frequency and duration of acid exposure as well as adequate oral hygiene measures, as it is known that eroded surfaces are more susceptible to abrasion. Biological factors, such as saliva or acquired pellicle, act protectively against erosive demineralization. Therefore, the production of saliva should be enhanced, especially in patients with hyposalivation or xerostomia. With regard to chemical factors, the modification of acidic solutions with ions, especially calcium, was shown to reduce the demineralization, but the efficacy depends on the other chemical factors, such as the type of acid. To enhance the remineralization of eroded surfaces and to prevent further progression of dental wear, high-concentrated fluoride applications are recommended. Currently, little information is available about the efficacy of other preventive strategies, such as calcium and laser application, as well as the use of matrix metalloproteinase inhibitors. Further studies considering these factors are required. In conclusion, preventive strategies for patients suffering from erosion are mainly obtained from in vitro and in situ studies and include dietary counseling, stimulation of salivary flow, optimization of fluoride regimens, modification of erosive beverages and adequate oral hygiene measures.
\end{abstract}

Key words: Dental erosion, prevention. Tooth wear.

\section{INTRODUCTION}

The term tooth wear is defined as loss of dental hard tissues due to the processes of dental erosion, attrition and abrasion $^{57}$. Dental attrition is the wear of tooth resulting from tooth to tooth contact ${ }^{57}$, while abrasion is caused by oral habits or abrasive substances, such as highly abrasive toothpastes ${ }^{57}$. Dental erosion is defined as the loss of tooth substance by chemical processes (acid exposure) not involving bacteria ${ }^{60}$. The acidic attack leads to an irreversible loss of dental hard tissue, which is accompanied by a progressive softening of the surface ${ }^{60}$. This softened zone is more susceptible to mechanical forces, such as abrasion ${ }^{82}$, which in turn have little or no effect on sound dental hard tissues ${ }^{1}$. The chemical and mechanical processes can occur individually or together, although the effect of erosion is often dominant ${ }^{2}$.

Clinically, early enamel erosion appears as a smooth silky-shining glazed surface (Figure 1). Typical for erosions of the facial aspects of teeth is a ridge of enamel that separates the defect from the marginal gingiva. Occlusal erosion is characterized by rounded cusps and concavities. Further progression of occlusal erosion lead to a distinct grooving of the cusps (Figure 2), and restorations are rising above the level of the adjacent tooth surface. In cases of severe erosion, the whole occlusal or facial morphology disappears. Erosion can be distinguished from wedge shaped lesions, which present a sharp margin in the coronal part and cuts at right angles into the enamel surface as well as from attrition. Attrition appears often glossy and has distinct 


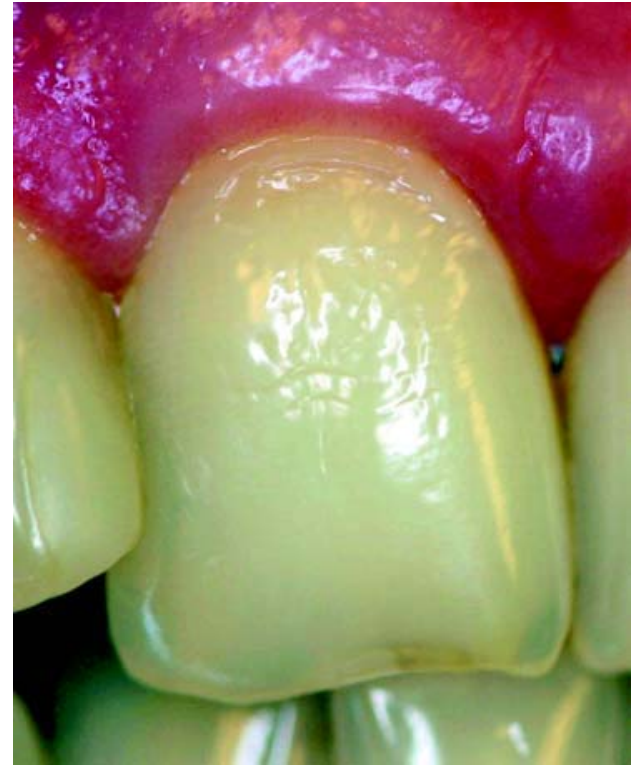

FIGURE 1- Clinical appearance of tooth wear in enamel. Enamel erosion in a 36-year-old female patient caused by frequent consumption of a cola soft drink. Erosion can be detected by the presence of a wedge-shaped defect, which shows a sharp margin on the coronal portion

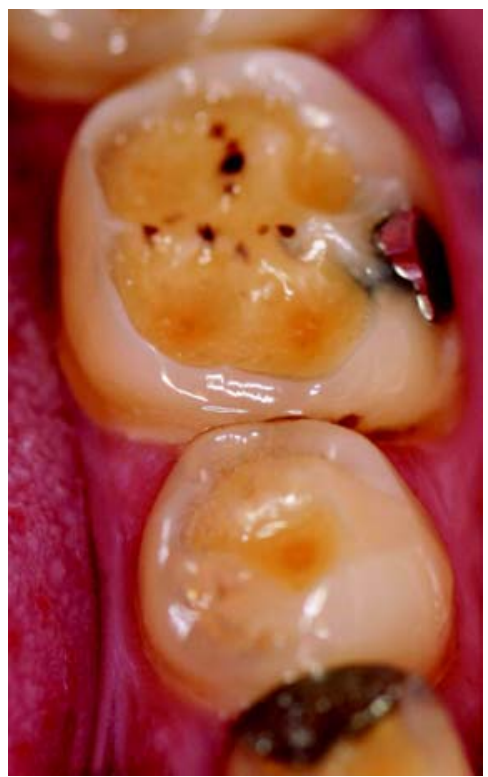

FIGURE 2- Clinical appearance of tooth wear in dentin in a 25-year-old athlete due to frequent consumption of acidic sport drinks

margins and corresponding features at the antagonistic teeth. In cases of occlusal tooth wear, the distinction between erosion and abrasion is often difficult, as both are of similar shape $^{29}$.

The etiology of erosion is multifactorial and not fully understood. The most important sources of acids are those found in the diet, such as acidic foods and drinks ${ }^{59}$ and those originated from the stomach, like gastric acids from regurgitation and reflux disorders ${ }^{16}$. Currently, the increased consumption of acidic foods and soft drinks is becoming an important factor for the development of erosive wear ${ }^{60}$.

As erosive tooth wear is a multifactorial condition, preventive strategies has to be applied which account for chemical, biological and behavioral factors involved in the etiology and pathogenesis of erosion ${ }^{60}$ (Figure 3 ). However, information is lacking about all possible preventive measures for erosion including those already known and the new ones. Therefore, the objective of this paper is to present an overview of the current literature and to summarize the preventive strategies relevant for patients suffering from dental erosion.

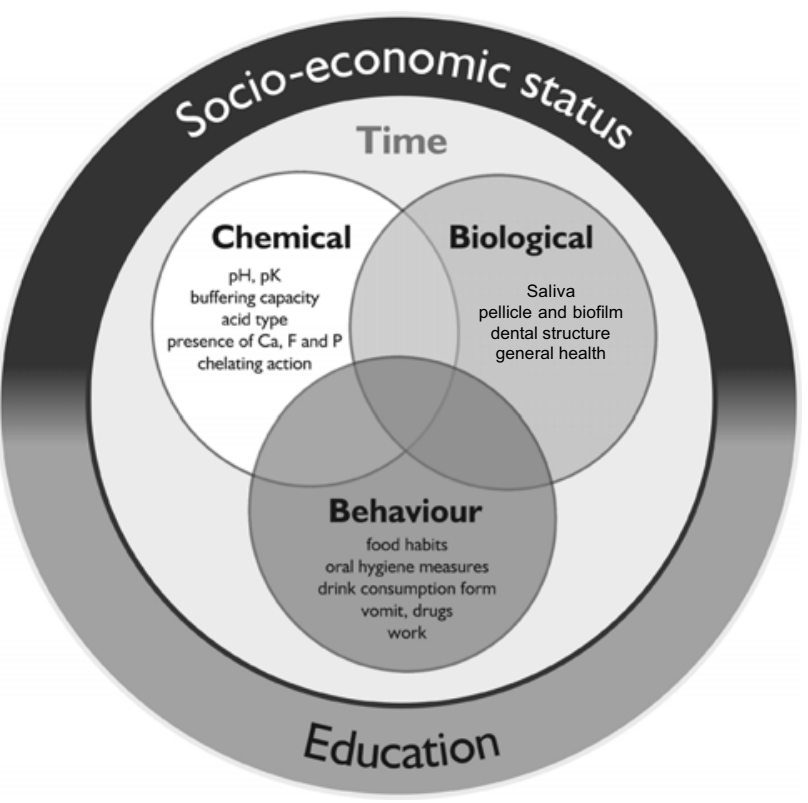

FIGURE 3- Diagram proposed by Lussi (2006), modified

\section{REVIEW OF LITERATURE AND DISCUSSION}

\section{Preventive Strategies for Behavioral Factors}

Behavioral factors have a decisive influence on the appearance and progression of dental erosion ${ }^{106}$. The frequent and excessive consumption of acids is associated with an increased risk for dental erosion. Special drinking habits, such as nipping from a bottle, might enhance the acid contact time and, thus, increase the erosive attack. Oral hygiene measures might also influence the progression of erosive lesions. Abrasive procedures, such as toothbrushing, are known to remove the fragile surface of demineralized dental hard tissues. In this way, the moment of toothbrushing after an erosive attack ${ }^{8,10}$ as well as the kind of toothbrush and toothpaste used might influence the progression of dental wear $^{40}$.

- Measures to Reduce the Acid Exposure

Of major importance for the prevention of dental erosion 
is the reduction of the acid exposure. The frequency and duration of acid contact might be important variables for the development of erosive lesions ${ }^{25,94}$. Moreover, the adhesiveness and displacement of liquids might influence the erosive process, as an increased adherence of an acidic substance is associated with a longer contact time on the tooth. The ability of beverages to adhere on enamel is based on their thermodynamic properties ${ }^{45}$.

Extrinsic acid sources of erosion are mainly dietary acids, but also lifestyle factors (e.g. drugs) or occupational acid exposure (Figure 4). To decrease the risk of dietary induced erosive lesions, patients should be advised to refuse from acidic snacks between the principal meals to allow the saliva to reharden eroded tooth surfaces. Special drinking habits, such as holding or moving the liquid in the mouth prior to swallowing, sucking from a straw or nipping from a bottle, lead to an increased acid contact time in the oral cavity and, thus, to prolonged duration of an acidic $\mathrm{pH}$-value in the environment of the teeth ${ }^{17}$. Therefore, it seems advisable to avoid these drinking habits to reduce the duration of the erosive attack (Figure 5). In addition to the dietary acids, patients should be aware of unhealthy lifestyle factors, such as consumption of drugs, alcohol abuse and lactovegetarian diet, which might increase the risk for erosion ${ }^{106}$ (Figure 4). However, as it is difficult to control possible etiological factors, such as the intake of acidic beverages or special drinking habits, other strategies have been developed for the prevention of dental erosion.

With regard to environmental acid exposure, an increased risk for dental erosion is reported for battery, charging and galvanizing workers, which are commonly exposed to sulphuric or hydrochloric acid (Figure 4). The risk for erosive tooth wear and the severity of erosion increase with increasing concentration of the acid or the acidic fumes, increasing exposure time and duration of employment. Personal protective equipments (respiratory masks) and adherence to threshold limit values recommended by occupational health legislations are considered as important preventive strategies to decrease occupational erosion ${ }^{96}$.

The intrinsic etiologic factors of erosion include disorders that are associated with the presence of gastric acid in the oral cavity, such as vomiting or gastroesophageal reflux (Figure 4). Therefore, erosive tooth wear is a common manifestation in patients suffering from organic or psychosomatic disorders like anorexia or bulimia nervosa or alcohol abuse. These disorders require a causal therapy (general medicine, psychological therapy) for a permanent reduction of the intrinsic acid exposure. However, dental professionals are often the first to discover and diagnose eating disorders by detecting structural changes of dental hard tissues and, thus, to induce general diagnostics and therapeutics (Figure 5).

\section{- Measures to Reduce the Mechanical Impact}

From in vitro ${ }^{91}$ and in situ studies ${ }^{31,98}$ it is concluded that the mechanical stress of eroded surfaces may be mainly induced by toothbrushing but also by attrition due to toothtooth-contact, tongue friction or abrasion of surrounding soft tissues under clinical conditions.

Attin, et al. ${ }^{8,10}$ showed that the resistance of eroded enamel and dentin to toothbrushing abrasion was significantly decreased after erosion, but was enhanced with increasing remineralization time. However, even after a remineralization period of $60 \mathrm{~min}$ the wear of enamel

\begin{tabular}{|c|c|}
\hline Diet & $\begin{array}{l}\text { Frequency of consumption of acid drinks (soft drinks, fruit juices, sport drinks) and foods } \\
\text { (citrus fruits, salad dressing), eventually diet diary }\end{array}$ \\
\hline \multirow[t]{9}{*}{ General diseases } & Gastrointestinal diseases (reflux) \\
\hline & Eating disorders \\
\hline & Alcohol abuse \\
\hline & General diseases affecting salivary flow rate \\
\hline & - Diseases of salivary glands \\
\hline & - Radiation of the head and neck region \\
\hline & - Sjögren-Syndrome \\
\hline & - Diabetes mellitus \\
\hline & - Chronic renal failure \\
\hline \multirow[t]{8}{*}{ Medication } & Acidic medicaments (acetylsalicylic acid, vitamin C) \\
\hline & Reduction of saliva secretion as a side effect of: \\
\hline & - Psychotropic drugs \\
\hline & - Anticholinergics \\
\hline & - Antihistaminics \\
\hline & - Antiemetics \\
\hline & - Parkinson medication \\
\hline & - Drugs abuse \\
\hline \multirow[t]{2}{*}{ Occupation/Sports } & Occupational acid exposure \\
\hline & Sports (swimming pool, increased consumption of acidic sport drinks) \\
\hline
\end{tabular}

FIGURE 4- Factors retrieved from a clinical interview indicating an increased risk for dental erosion 


\begin{tabular}{|c|c|}
\hline $\begin{array}{l}\qquad \text { Aim } \\
\text { Reduction of acid exposure }\end{array}$ & Recommendation/Measure \\
\hline - Extrinsic factors (e.g. diet) & $\begin{array}{l}\text { Reduction of the intake of acidic drinks and snacks } \\
\text { - Acidic beverages should be drunk quickly and cooled } \\
\text { - Consumption of acidic drinks with a high content of calcium, phosphate, } \\
\text { fluoride and xylitol }\end{array}$ \\
\hline - Intrinsic factors & $\begin{array}{l}\text { Evaluation of the etiology of acid exposure, therapy of organic (e.g. reflux, } \\
\text { xerostomia) or psychosomatic (e.g. bulimia nervosa) disorders }\end{array}$ \\
\hline $\begin{array}{l}\text { Reduction of demineralization, } \\
\text { enhancement of remineralization }\end{array}$ & $\begin{array}{l}\text { - Increase of salivary flow } \\
\text { - Chewing of sugar-free gums } \\
\text { - Patients with xerostomia: systemic medication (cholinergic drugs), use } \\
\text { of saliva substitutes } \\
\text { - Behavior after acid contact } \\
\text { - Rinsing of the oral cavity with water, milk or low concentrated fluoride } \\
\text { solutions } \\
\text { - Consumptions of neutralizing food (cheese, milk) } \\
\text { - Frequent fluoridation } \\
\text { - Use of fluoridated toothpaste, solution and gel }\end{array}$ \\
\hline Reduction of abrasion & $\begin{array}{l}\text { - No toothbrushing immediately after acid consumption } \\
\text { - Use of manual toothbrushes or electric toothbrushes applied with gentle } \\
\text { pressure } \\
\text { - Use of fluoridated toothpastes with low REA/RDA-value }\end{array}$ \\
\hline
\end{tabular}

FIGURE 5- Preventive measures for patients with increased risk for erosion

samples was significantly increased as compared to the demineralized, but not brushed control ${ }^{8}$. In contrast, dentin wear was not significantly higher than in unbrushed controls after intra-oral periods of 30 and $60 \mathrm{~min}^{10}$. Thus, patients who present high risk for dental wear should be recommended to avoid toothbrushing immediately after an acidic attack, but wait at least 30-60 min (Figure 5).

In addition to the moment of toothbrushing, abrasion of eroded enamel and dentin is dependent on the type of toothbrush, the applied brushing force and several toothpaste factors ${ }^{40,97,99,101,103,105}$. Previous studies ${ }^{97,99,101}$ have shown that powered and manual toothbrushes as well as manual toothbrushes applied with different brushing loads vary in their ability to remove the fragile surface of demineralized enamel and dentin. On the basis of the observation that enamel and dentin wear increase with increasing toothbrushing force ${ }^{99}$, patients with erosive lesions should apply their toothbrushes with slight pressure to minimize loss of dental hard tissues (Figure 5).

The stiffness of the toothbrush bristles seems to be of minor importance for the abrasion of eroded dental hard tissues. Wiegand, et al. ${ }^{103}$ showed that the ability of toothbrushes with filament diameters of $0.15,0.20$ and 0.25 $\mathrm{mm}$ to remove eroded enamel did not differ significantly when toothpaste slurries of REA 2, 6 and 9 were used.

In contrast, toothbrushing abrasion is mainly influenced by the toothpaste used ${ }^{103}$. The abrasivity of the toothpaste is determined by the size and amount of abrasives, $\mathrm{pH}$, buffering capacity and fluoride concentration. Generally, enamel and dentin loss increases with increasing abrasivity (determined by the REA and RDA-value of the toothpaste $)^{40,103}$. Fluoridated toothpastes might not only reduce the erosive demineralization, but also reduce the abrasion of eroded tissues ${ }^{64,67}$. Therefore, patients with erosive lesions should use fluoridated toothpastes with low abrasivity for their oral hygiene measures.

\section{Preventive Strategies for Biological Factors}

With regard to biological factors, the quality of dental tissues, properties of saliva, tooth position and anatomy of the soft tissues might affect the development of dental erosion. Severe erosive lesions affect not only the enamel surface, but also might lead to the exposure of coronal or radicular dentin and, thus, to painful hypersensitivity. Moreover, erosive tooth wear is not only found in permanent teeth, but also is increasingly reported in the primary dentition ${ }^{39}$.

\section{- Progression of Erosion In Different Tissues}

The interaction between erosive agents and dental tissues is different for enamel and dentin, and for primary and permanent teeth. Basically, permanent enamel is composed 
by mineral ( $85 \%$ volume), in the form of (hydroxy or fluor) apatite crystals organized in prisms. At a $\mathrm{pH}$ less than 4.5, the apatite crystals are easily dissolved by acids, generating a surface lesion (Figure 6) with concave clinical appearance (Figures 1 and 2). Permanent dentin contains inorganic-47\% (apatite), organic-33\% (collagen) components and water$20 \%$. Studies have shown that demineralization of dentin is firstly apparent at the interface between inter- and peritubular dentin. With increasing exposure time, the erosive attack results in a hollowing and funneling of the tubules. Finally, the peritubular dentin is completely dissolved. Erosive demineralization results in exposure of an outer layer of fully demineralized organic matrix followed by a partly demineralized zone until the sound inner dentin is reached ${ }^{50}$ (Figure 7). The dentin demineralization rate decreases when the amount of degradable collagen increases, whereby the demineralized matrix is attributed to hamper ionic diffusion into and out of the demineralizing area ${ }^{27,28}$. On the other hand, the erosion time of enamel is linear over time ${ }^{26}$.

In addition, primary enamel and dentin are thinner than permanent. Therefore, the erosive process reaches the dentin earlier and leads to an advanced lesion after a shorter exposure period to acids, compared to permanent teeth ${ }^{4}$. However, studies about the susceptibility of these teeth to erosive softening have revealed conflicting results. While several authors found an increased susceptibility to erosion in primary teeth, others found no difference between primary and permanent dental hard tissues ${ }^{4,44,56}$.

\section{- Measures to Increase the Quality and the Quantity of Saliva and Pellicle}

Saliva seems to play an important role in minimizing enamel and dentin wear in erosive/abrasive attacks due to its buffering and remineralizing capacities as well as the ability to form a protective pellicle layer on dental hard tissues $^{35,69}$. Xerostomia or hyposalivation is a condition frequently observed in patients undergoing radiation therapy on the head and neck region, but is also common in patients suffering from diseases of the salivary glands (Sjögren syndrome) or can be induced by several systemic medications (Figure 4). In these patients, the decreased salivary flow rate is associated with a low $\mathrm{pH}$ of the saliva and a decreased buffering capacity ${ }^{70}$. It has been shown that low salivary flow rate and low buffering capacity are strongly associated with dental erosion ${ }^{75}$.

Salivary flow stimulation can yield an increase in bicarbonate buffer and in salivary mineral content, which can facilitate calcium and phosphate redeposition onto the enamel and dentin surface and reduction of dental tissue $\operatorname{loss}^{24}$ (Figure 5). Rios, et al. ${ }^{83}$ showed that saliva stimulated by the use of sugar-free chewing gum promoted a remineralizing action in the erosive/abrasive phenomena. In contrast, sucking of acidic candies might change the whole-mouth saliva composition so that it may have erosive potential ${ }^{46}$

This remineralizing effect might be increased by rinsing with milk or eating cheese, which are of interest as they contain higher levels of calcium and phosphate than water or saliva and, therefore, may act as donor of calcium and phosphate for remineralization ${ }^{33}$ (Figure 5). Although the consumption of milk or cheese is frequently recommended to enhance the rehardening of demineralized dental hard tissues, only few authors have yet investigated their effects on enamel demineralization ${ }^{33}$.

Besides local saliva stimulators like chewing gum, the salivary flow rate can also be increased systemically. Thus, patients suffering from xerostomia are often treated by cholinergic drugs, such as pilocarpine. Moreover, saliva substitutes might provide relief of the oral symptoms. Saliva substitutes should be of neutral $\mathrm{pH}$ to prevent dental hard tissue demineralization and should be saturated with respect to calcium and phosphate to gain remineralizing potential ${ }^{71}$ (Figure 5).

Saliva is also responsible for the formation of the acquired pellicle, which is a physical barrier that protects the tooth against erosive attacks. It is composed of a protein layer formed on tooth surface, acting as a diffusion barrier or permeability membrane ${ }^{39,69}$. This selective barrier prevents the direct contact between acids and the tooth surface, thus reducing the dissolution of hydroxyapatite. Protection of the tooth surface by the acquired pellicle is well established in the literature and has been demonstrated by several studies $^{37,38}$

Pellicle thickness varies within the dental arches and among individuals ${ }^{3}$. An inverse relationship was observed between the degree of erosion and pellicle thickness. This relationship suggests that the thickness of the acquired salivary pellicle may be an important factor for sitespecificity of dental erosion ${ }^{3,6}$. Conflicting results have been published regarding the impact of the formation time on the protective properties of the pellicle layer ${ }^{38}$. However, it is generally accepted that the function of the pellicle as a diffusion barrier to ionic conductivity on the enamel surface is improved with the process of pellicle maturation ${ }^{37}$.

It is important to point out that the pellicle is not totally dissolved from the enamel surface, but rather gradually from its external to basal components. This fact suggests a partial acid resistance of the in vivo formed pellicle layers ${ }^{37}$. As toothbrushing can remove parts of the salivary pellicle ${ }^{47}$, patients at risk of dental erosion should diminish the frequency of toothbrushing and use dentifrice with low abrasiveness to avoid damaging of the acquired pellicle (Figure 5).

\section{Preventive Strategies for Chemical Factors}

The chemical factors relevant for the erosion capacity of an acid solution are the type and quantity of the acid, the $\mathrm{pH}$, buffering capacity and temperature as well as the presence of chelating agents and the concentration of phosphate, calcium and fluoride ${ }^{58,94}$. Fruit juices, soft drinks, vinegar and ice tea are known as highly erosive, as they are composed of acids (citric, phosphoric, acetic acids) with a $\mathrm{pH}$ lower than 4.5. Usually they are unsaturated regarding to apatite and present a high buffering capacity ${ }^{59}$.

- Fluoride and Metal Fluoride Application

The impact of fluoride treatment on the progression of 


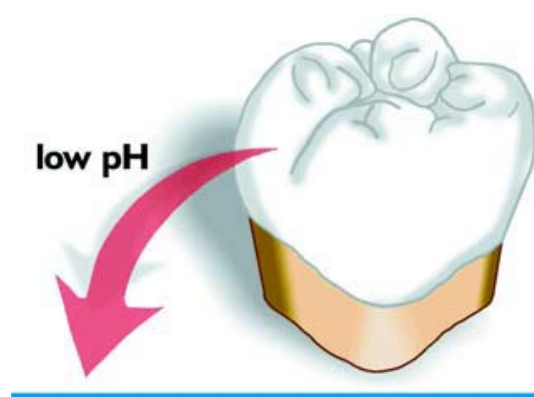

\section{Dental enamel}

Erosive challenge $(\mathrm{pH}<4.5)$

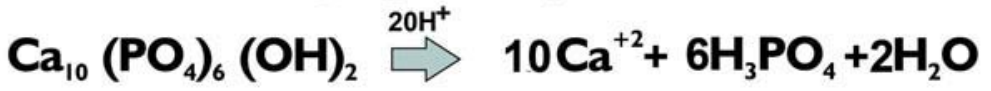

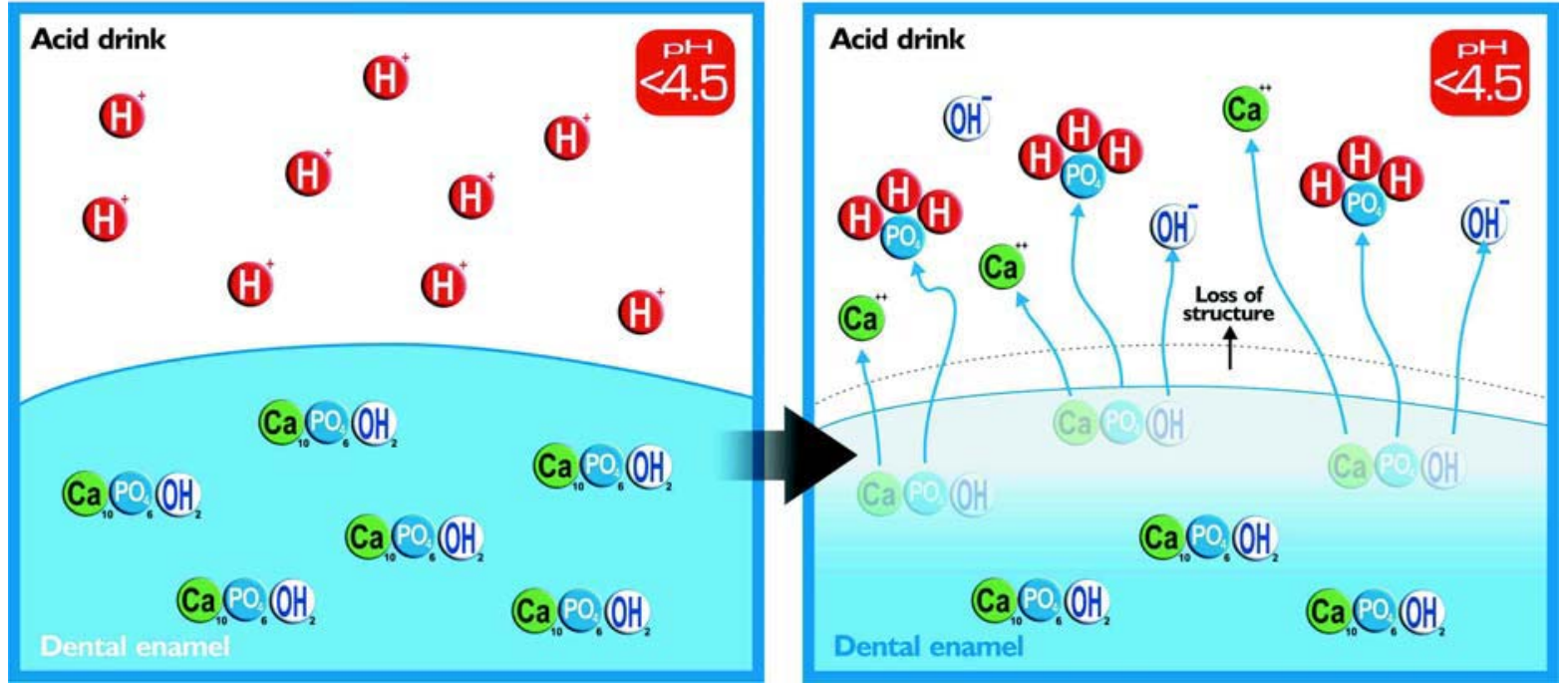

FIGURE 6- Erosive demineralization of dental enamel $(\mathrm{pH}<4.5)$

\section{Dentin (LONGITUDINAL VIEW)}

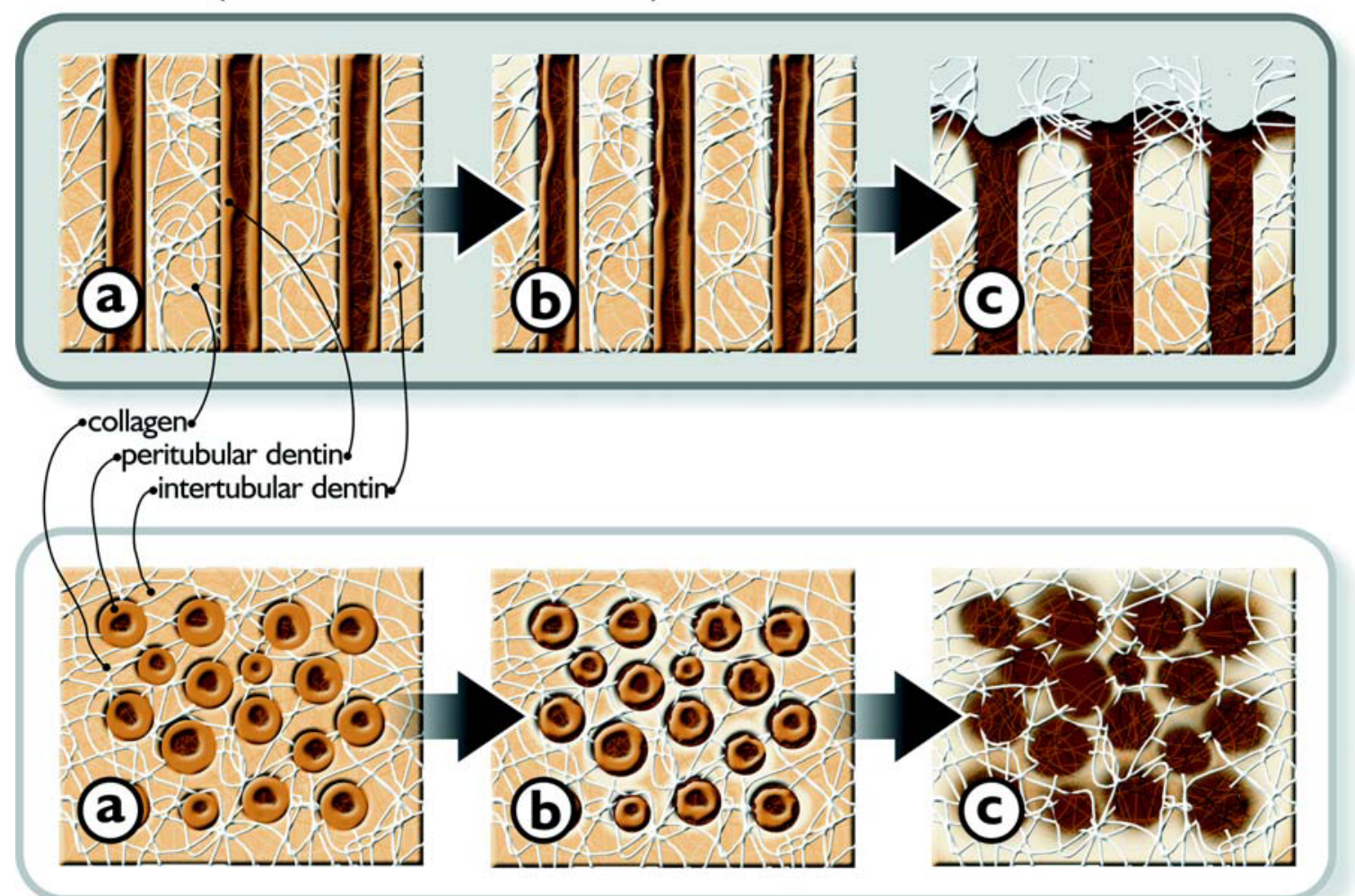

\section{Dentin (CROSS SECTIONAL VIEW)}

FIGURE 7- Erosive demineralization of dentin (longitudinal and cross-sectional view). a-c. Progression of the erosion process in dentin (a. sound dentin, b. initial demineralization, c. exposure of organic matrix) 
enamel and dentin erosion has been analyzed in several studies. The action of fluoride is mainly attributed to a precipitation of $\mathrm{CaF}_{2}$-like material on eroded dental surfaces ${ }^{26,27}$. The formation of the $\mathrm{CaF}_{2}$-like layer and its protective effect on demineralization depend on the $\mathrm{pH}, \mathrm{F}$ concentration and type of $\mathrm{F}$ salt of the agent ${ }^{86}$. However, the role of fluoride application on the prevention of dental erosion is still controversially discussed ${ }^{95}$, since the deposited calcium fluoride-like material from topical fluoride application is supposed to be readily dissolved in most acidic drinks ${ }^{30}$.

High-concentrated fluoride agents, such as oral rinses, gels or varnishes, have been demonstrated to increase abrasion resistance and decrease the development of enamel and dentin erosion in vitro and in situ ${ }^{26,51}$. Most studies focusing on the preventive effect of fluoride on erosion used fluoride compounds that have been used over years in caries prevention, such as $\mathrm{NaF}, \mathrm{AmF}, \mathrm{SnF}_{2}$ or acidulated phosphate fluoride (APF) (12,300 to 22,600 ppm F, pH 1.0 to 7.0). Although the results of a recent in vitro study ${ }^{32}$ suggest considerable differences between $\mathrm{NaF}, \mathrm{AmF}$ and $\mathrm{SnF}_{2}$, the impact of different fluoride compounds on erosion has not yet been analyzed under clinical conditions. The efficacy of fluorides to affect de- and remineralization is related to its concentration and depends on the $\mathrm{pH}$ of the fluoride agent. It is known that the formation of $\mathrm{a} \mathrm{CaF}_{2}$ reservoir is increased under acidic compared to neutral conditions ${ }^{88}$. Depending on the study design, the application of high-concentrated fluoride agents might lead to a nearly complete reduction of dental erosion.

In contrast to the application of highly fluoridated agents, a 1,000 ppm $F$ dentifrice was shown to have a limited beneficial effect compared to non-fluoridated dentifrices on abrasion of eroded dentin and ename ${ }^{64,78}$. However, a recent in situ study showed that a 5,000 ppm F dentifrice had the same effect as a 1,100 ppm F dentifrice on eroded and eroded and abraded dentin ${ }^{67}$. Also for enamel wear, no significant differences were found among 1,100 and 5,000 ppm F dentifrices ${ }^{84}$. Overall, the efficacy of a fluoridated dentifrice is not increasing along with the $\mathrm{F}$ concentration in dentifrices containing more than $1,000 \mathrm{ppm} F$ and the reduction of wear seems to be less than $30 \%$ for this fluoride vehicle compared to placebo ${ }^{67,84}$.

More recently, other agents, such as tetrafluorides $\left(\mathrm{TiF}_{4}\right.$ $\mathrm{ZrF}_{4}, \mathrm{HfF}_{4}$ in a concentration between 0.4 to $10 \%, \mathrm{pH} \mathrm{1-2),}$ especially titanium tetrafluoride, have been investigated for erosion prevention ${ }^{41,42,65,87,91,92,100,102}$. With regard to $\mathrm{TiF}_{4}$ solution, several in vitro studies have shown an inhibitory effect on dental erosion ${ }^{41,42,87}$, which is attributed not only to the effect of fluoride, but also to the action of titanium. It is speculated that the titanium ions might play an important role as they might substitute calcium in the apatite lattice and show a strong tendency to complex with phosphate groups, forming a stable titanium dioxide layer ${ }^{72,81}$. Moreover, it is suggested that titanium interacts with the enamel surface, thus leading to an increased fluoride uptake by enamel ${ }^{72}$. However, other studies have not found a protective effect of $\mathrm{TiF}_{4}$ against erosion or combined erosion and abrasion ${ }^{65,91,92}$. Recently, an in vitro study comparing the efficacy of a $4 \% \mathrm{TiF}_{4}$ solution, an experimental $4 \% \mathrm{TiF}_{4}$ varnish and commercial $\mathrm{NaF}$ varnishes on the progression of enamel erosion was performed. The experimental $\mathrm{TiF}_{4}$ varnish showed the best protective effect when compared to commercial $\mathrm{NaF}$ varnishes, while $\mathrm{TiF}_{4}$ solution was not effective to reduce the enamel wear ${ }^{62}$. However, $\mathrm{TiF}_{4}$ agents have a very acidic $\mathrm{pH}(\mathrm{pH} 1-2)$, which does not allow for patient self-application.

Overall, the protective impact of high-concentrated fluoride applications on the progression of erosive lesions has been shown both in vitro and in situ, but clinical studies giving support for this observation are not yet available. It is interesting that the fluoridation effects might be more enhanced in dentin than in enamel ${ }^{26}$. The buffering effect of the demineralized matrix reduces the $\mathrm{pH}$ drop within this layer. Together with the presence of high concentrations of fluoride, this might reduce further dentin demineralization ${ }^{27}$. Also, metal fluorides might be more effective in dentin than in ename $1^{87,102}$, since it is assumed that the metals (titanium ion) might play an essential role because of its complex ability and protein-binding properties ${ }^{72}$. Based on the findings of in vitro and in situ studies, it seems valid to recommend high-concentrated fluoride applications for prevention of dental erosion (Figure 5). The application of high-concentrated agents has to be done by a dentist, taking care for the quantity and for avoiding that the patient swallows the product. If these cares are taken, even the frequent application of high-concentrated agents seems to be safe. However, clinical and epidemiological studies are required to confirm the promising results found in vitro and in situ.

\section{- Modification of acid solutions and beverages}

In the daily life situation, preventive strategies influencing biological and behavioral factors might be of limited impact as they are highly dependent on the patient's compliance. Thus, it seems to be of great interest to develop preventive strategies, which are less dependent on the patient's behavior.

One preventive strategy might be the reduction of the erosive potential of acidic beverages by ions supplementation (calcium, phosphate and fluoride). The addition of calcium has been shown to reduce the erosive potential of pure acids and acidic drinks, especially on enamel erosion ${ }^{14,15,43}$ (Figure 5).

Orange juice ( $\mathrm{pH} 4.0)$ supplemented with $40 \mathrm{mmol} / \mathrm{L}$ calcium and $30 \mathrm{mmol} / \mathrm{L}$ phosphate did not erode the enamel as calcium and phosphate saturated the drink with respect to apatite ${ }^{53}$. Attin, et al. ${ }^{9}$ showed that Ca supplementation of $0.5-1.5 \mathrm{mmol} / \mathrm{L}$ was effective in reducing the erosive potential of citric acid, while the addition of $\mathrm{F}$ and $\mathrm{P}$ failed to reduce the erosive capacity. Saturation with $\mathrm{CaF}_{2}$ reduced the in vitro development of erosions by $28 \%$ induced by drinks with $\mathrm{pH}$ above 3 ; in drinks with $\mathrm{pH}$ below 3 , erosions were not affected by fluoride concentrations up to $20 \mathrm{ppm}^{54}$.

Larsen and Nyvad ${ }^{53}$ and Larsen and Richards ${ }^{54}$ showed that fluoride admixtures in a concentration excluding 
toxicological side effects seem unable to reduce erosive lesions. The supplementation of low levels of calcium, phosphate and fluoride was not effective in decreasing the erosive potential of solutions with a $\mathrm{pH}$ below 4.0 in the above-mentioned studies. Amaechi, et al. ${ }^{5}$ found that the supplementation of an orange juice with xylitol $(25 \% \mathrm{w} / \mathrm{v})$ and fluoride $(0.5 \mathrm{ppm})$ had an additive effect on the reducing dental erosion in vitro. Xylitol might form complexes with calcium, penetrate into demineralized enamel and interfere with the transport of dissolved ions from the lesion to the demineralizing solution by lowering the diffusion coefficient of calcium and phosphate ions from the lesion into the solution ${ }^{7,68}$.

Alternatively, acidic solutions can be supplemented with metal ions, such as iron, which seems to decrease the erosive potential of acidic solutions ${ }^{18,48}$. Iron can participate in the remineralization of human enamel, in the nucleation of apatite, substitution of calcium in apatite and inhibition of demineralization ${ }^{12}$. In addition, rinsing with an iron solution after an erosive attack can significantly reduce dentin wear by erosion or combined erosion-abrasion ${ }^{85}$. It is important to highlight that studies analyzing the effect of iron supplementation to soft drinks or acid solutions, used high concentrations of iron, which might exhibit toxic effects ${ }^{18,48}$. Buzalaf, et al. ${ }^{18}$ investigated the protective effect of crescent concentrations $(0-120 \mathrm{mmol} / \mathrm{L})$ of iron on dissolution of enamel by acetic acid and showed that the $15 \mathrm{mM}$ Fe was able to reduce the enamel dissolution. Kato, et al. ${ }^{48}$ showed that iron $(10 \mathrm{mM} \mathrm{Fe})$ can interfere with the dissolution of dental enamel powder in the presence of acidic beverages. This effect seems to be modulated by the type of acid. Interestingly, these authors found that higher concentrations of Fe were effective to inhibit dental erosion by a cola drink (Coke, phosphoric acid), but not by a drink containing citric acid (Sprite). On the other hand, the admixture of low concentrations of Fe (1 mM) into a soft drink (Sprite Zero) was not able to reduce the enamel $\operatorname{loss}^{63}$. In addition, the supplementation of iron may lead to a metallic taste of the soft drink and might affect tooth color and the taste of other foods.

Due to the possibility of a synergistic effect among different ions, it could be speculated that it might be possible to increase their beneficial effects with much lower doses by using the adequate combination of these ions ${ }^{9,11}$. Attin, et al. ${ }^{11}$ showed that the combination of low levels of $\mathrm{Ca}(0.5$ $\mathrm{mM}), \mathrm{P}(0.5 \mathrm{mM})$ and $\mathrm{F}(0.037 \mathrm{mM})$ is able to reduce enamel loss. These authors revealed that the mixture of $\mathrm{Ca}$ alone or in combination with $\mathrm{P}$ and $\mathrm{F}$ was effective to reduce the dental loss by Sprite, but not by Coke. On the other hand, the admixture $1 \mathrm{mM} \mathrm{Ca}, 1 \mathrm{mM} \mathrm{Fe}, 1 \mathrm{mM} \mathrm{P}$ and $0.047 \mathrm{mM} \mathrm{F}$ to a soft drink (Sprite Zero) was not effective to decrease the erosive potential ${ }^{63}$

The erosive potential of soft drinks and acidic beverages can be also decreased by replacing highly erosive acids by acids with lower erosive capacity. Citric acid is for instance known to exhibit a greater erosive capacity than hydrochloric and phosphoric acids ${ }^{36,94,104}$. The greater erosive potential of citric acid might be related to its ability to form chelating complexes with calcium. Moreover, differences in their specific interaction with hydroxyapatite might influence the erosive potential of different mono-, di- and tri-carboxylic $\operatorname{acids}^{104}$

To summarize the above mentioned-studies critically, the efficacy of ion supplementation depends not only on the mineral content, but also on various factors, such as acid type, $\mathrm{pH}$, amount of titratable acid and buffering capacity of the acid solution ${ }^{53,58}$. Therefore, further research taking into account these factors is requires, with special emphasis on the consequences of taste alterations, stability of the solution and systemic effects for the patients. Studies evaluating the effects of soft drink modification on dentin erosion should also be performed.

\section{Further Studies}

\section{Calcium Application}

Studies involving dental caries suggest that increased salivary and plaque calcium concentrations might enhance fluoride uptake and retention and, thus, increase the action of fluoride in the de- and remineralization process. In order to increase the saliva or plaque calcium content, several calcium compounds in form of rinses, dentifrices or chewing gums have been investigated ${ }^{20,61,76,93}$. Regarding dental erosion, it is reasonable to increase the salivary calcium concentration, which might enhance fluoride deposition on the dental tissues by formation of a $\mathrm{CaF}_{2}$-like reservoir.

There are currently only few studies about the effect of calcium-rich toothpastes on dental erosion. Lennon, et al. ${ }^{55}$ analyzed the effect of a casein/calcium phosphate-containing tooth cream (Topacal) on enamel erosion in vitro. Topacal or a combination of Topacal and a $250 \mathrm{ppm}$ fluoride solution provided only little protection against erosion and were significantly less effective than a highly fluoridated amine fluoride gel. In contrast, Rees, et al. ${ }^{79}$ and Piekarz, et al. ${ }^{77}$ found that Tooth Mousse (CPP-ACP: Casein phosphopeptide - amorphous calcium phosphate) significantly reduced enamel erosion in vitro. Due to the lack of available data, final conclusions about the efficacy of calcium-rich products on dental erosion can not be drawn so far. Further studies must be performed testing the preventive effect of calcium solutions and calcium-rich dentifrices on enamel and dentin erosion.

\section{- Laser Application}

The protective effects of laser application on enamel and dentin demineralization have gained increasing attention in the last years. Several types of lasers, such as ruby, $\mathrm{CO}_{2}$, Nd:YAG and argon, with different operative modes and energy outputs have been investigated. The laser treatment causes several chemical changes on tooth surface, including the reduction of the carbonate content and the exchange of hydroxyapatite to fluorapatite when applied with fluoride vehicles $^{74}$. In addition, laser application melts and solidifies the dental surface, creating a smoother new surface ${ }^{52,74}$. The melted enamel surface can show a crystal growth that can reduce the interprismatic spaces and consequently, the 
diffusion of acids during an acid challenge ${ }^{22}$. All these chemical and morphological changes of the dental surface might lead to a decreased susceptibility to erosive demineralization.

However, there are few studies available testing the effect of the laser application on the prevention of erosive demineralization and most of them are related to carious and not erosive demineralization. Tsai, et al. ${ }^{90}$ compared the effectiveness of laser treatment (pulsed $\mathrm{CO}_{2}$ and pulsed $\mathrm{Nd}$ :YAG $-83.33 \mathrm{~J} / \mathrm{cm}^{2}$ ) on the acid resistance of human enamel in vitro. The Nd:YAG laser was not able to increase the enamel resistance to an acid challenge (lactate buffer solution, $\mathrm{pH} \mathrm{4.5,} 24$ and $72 \mathrm{~h}$ ). In contrast, the application of Nd:YAG laser $(0.5,0.75$ and $1 \mathrm{~W})$ combined or not to fluoride application (fluoride gel and varnish) significantly reduced the enamel erosive wear in a 5-day-in vitro study ${ }^{19}$. Additionally, when the erosive challenge was extended to 10 days, the combined application of Nd:YAG laser and fluoridated gel was still effective on the reduction of the enamel wear, which could be attributed to the low $\mathrm{pH}$ of the fluoride agent ${ }^{19}$.

Regarding dentin, Naylor, et al..$^{73}$ showed that irradiation with Nd:YAG laser produces obliteration of dentinal tubules as well as a melting and resolidification, with the formation of recrystallization granules. The authors suggested that dentin irradiated with $0.6 \mathrm{~W} \mathrm{Nd:YAG} \mathrm{laser} \mathrm{presented} \mathrm{a}$ higher resistance to acidic beverages such as cola soft drink and passion fruit juice. On the other hand, Magalhães, et al. ${ }^{66}$ showed that the application of Nd:YAG laser $(0.5,0.75$ and $1 \mathrm{~W}$ ) was unable to reduce the dentin erosive wear.

Due to the few data available so far, final conclusions about the efficacy of laser application on dental erosion cannot be drawn as yet. Further studies are necessary to clarify this topic.

- MMPs (matrix metalloproteinases) inhibitors agents

Matrix metalloproteinases (MMPs) are responsible for hydrolyzing the components of the extracellular matrix (ECM) during the remodeling and degradation processes in the oral environment. Thus, the organic matrix of dentin (collagen) can be degraded by MMPs present in dentin and saliva. The balance between activated MMPs and tissue inhibitors of metalloproteinases (TIMPs) controls the extent of ECM remodeling/degradation ${ }^{80}$. The activation of MMPs seems to play a role in dentinal caries progression, since they have a crucial role in the collagen breakdown in caries lesions. Individuals with a high concentration of MMPs in saliva present an increased susceptibility to dental caries ${ }^{23}$. MMPs implicated in collagen degradation in dentin are MMPs 2, 8, and $9^{89}$. In addition, the phosphorylated proteins released during the dentin matrix demineralization could interact with TIMP-inhibited host MMPs within the lesion and reactivate them, thus enhancing the degrading activity. Despite the lack in studies investigating the role of MMPs in dental erosion, processes similar to the caries process can be assumed for erosive lesions.

Tjäderhane, et al. ${ }^{89}$ found that the latent forms of MMP 2 and MMP 9 can be activated in acidic conditions followed by neutralization, as it occurs during the carious process when the $\mathrm{pH}$ in dental plaque drops within minutes after sugar ingestion until neutralized by salivary buffers. The exposed demineralized dentin matrix is assumed to hamper ionic diffusion into and out of the demineralizing area. Therefore, a destruction of the collagen layer by host dentin MMPs is expected to increase the progression of dental caries in human teeth ${ }^{89}$.

Due to the involvement of host MMPs to the progression of dental caries in human teeth, it might be interesting to find MMP inhibitors for patients with high risk for caries but also for erosion ${ }^{13}$. Green tea polyphenols, especially epigallocatechin gallate (EGCG), were found to have distinct inhibitory activities against $\mathrm{MMPs}^{23}$. A recent study about the preventive effect of green tea on dentin wear has shown that the rinse with green tea reduced dentin erosion and abrasion in situ ${ }^{49}$.

Other potential MMP inhibitors are chlorhexidine (CHX), an antibacterial agent, which was found to inhibit the activity of MMPs 2, 8 and $9^{34}$, as well as natural products such as avocado, soya bean and oleic acid ${ }^{23}$. CHX presents beneficial effects on the preservation of dentin bond strength in vivo, as an MMP inhibitor ${ }^{21}$, when applied between the acid attack and the bonding procedures. However, the mechanisms of action of these agents and their impact on dental erosion have not been investigated yet. Therefore, this topic might be of interest in further research on the prevention of dental erosion.

\section{CONCLUSION}

From the available data of in vitro and in situ studies, preventive strategies for patients suffering from erosion include dietary advice, stimulation of salivary flow, optimization of fluoride regimens, modification of erosive beverages and adequate oral hygiene measures. However, clinical trials are required to confirm the relevance of these measures. As erosive tooth wear cannot be prevented totally with the recommended strategies, further research is necessary to develop new measures with higher protective capabilities and good clinical acceptance.

\section{REFERENCES}

1- Addy M, Hunter ML. Can tooth brushing damage your health? Effects on oral and dental tissues. Int Dent J. 2003;53:177-86.

2- Addy M, Shellis RP. Interaction between attrition, abrasion and erosion in tooth wear. Monogr Oral Sci. 2006;20:17-31.

3- Amaechi BT, Higham SM, Edgar WM, Milosevic A. Thickness of acquired salivary pellicle as a determinant of the sites of dental erosion. $\mathrm{J}$ Dent Res. 1999;78:1821-8.

4- Amaechi BT, Higham SM, Edgar WM. Factors influencing the development of dental erosion in vitro: enamel type, temperature and exposure time. J Oral Rehabil. 1999;26:624-30. 
5- Amaechi BT, Higham SM, Edgar WM. The influence of xylitol and fluoride on dental erosion in vitro. Arch Oral Biol. 1998;43:157-61.

6- Amaechi BT, Higham SM. Eroded enamel lesion remineralization by saliva as a possible factor in the site-specificity of human dental erosion. Arch Oral Biol. 2001;46:697-703.

7- Arends J, Christoffersen J, Schuthof J, Smites MT. Influence of xylitol on demineralization of enamel. Caries Res. 1984;18:296-301.

8- Attin T, Knöfel S, Buchalla W, Tütüncü R. In situ evaluation of different remineralization periods to decrease brushing abrasion of demineralised enamel. Caries Res. 2001;35:216-22.

9- Attin T, Meyer K, Hellwig E, Buchalla W, Lennon AM. Effect of mineral supplements to citric acid on enamel erosion. Arch Oral Biol. 2003;48:7539.

10- Attin T, Siegel S, Buchalla W, Lennon AM, Hannig C, Becker K. Brushing abrasion of softened and remineralized dentin: an in situ study. Caries Res. 2004;38:62-6.

11- Attin T, Weiss K, Becker K, Buchalla W, Wiegand A. Impact of modified acidic soft drinks on enamel erosion. Oral Dis. 2005;11:7-12.

12- Bachra BN, Van Harskamp GA. The effect of polyvalent ions on the stability of a buffer system for calcification in vitro. Calcif Tissue Res. 1970;4:358-65

13- Baker AH, Edwards DR, Murphy G. Metalloproteinase inhibitors biological actions and therapeutic opportunities. J Cell Sci. 2002;115:3719-27

14- Barbour ME, Parker DM, Allen GC, Jandt KD. Enamel dissolution in citric acid as a function of calcium and phosphate concentrations and degree of saturation with respect to hydroxyapatite. Eur J Oral Sci. $2003 ; 111: 428-33$.

15- Barbour ME, Parker DM, Allen GC, Jandt KD. Human enamel erosion in constant composition citric acid solutions as a function of degree of saturation with respect to hydroxyapatite. J Oral Rehabil. 2005;32:1621.

16- Bartlett D. Intrinsic causes of erosion. Monogr Oral Sci. 2006;20:11939.

17- Bassiouny MA, Yang J. Influence of drinking patterns of carbonated beverages on dental erosion. Gen Dent. 2005;53:205-21.

18- Buzalaf MA, Moraes I, Kato MT, Martinhon CC, Magalhaes AC. Effect of iron on inhibition of acid demineralisation of bovine dental enamel in vitro. Arch Oral Biol. 2006;51:844-8.

19- Buzalaf MAR, Rios D, Magalhães AC, Machado MAAM, Silva SMB Lizarelli RFZ, et al. The effect of Nd:YAG irradiation and fluoride application on enamel resistance to erosion. Caries Res. 2008;42:191.

20- Cai F, Manton DJ, Shen P, Walker GD, Cross KJ, Yuan Y et al. Effect of addition of citric acid and casein phosphopeptide-amorphous calcium phosphate to a sugar-free chewing gum enamel remineralisation in situ. Caries Res. 2007;41:377-83.

21- Carrilho MR, Geraldeli S, Tay F, de Goes MF, Carvalho RM, Tjaderhane L, et al. In vivo preservation of the hybrid layer by chlorhexidine. J Dent Res. 2007;86:529-33

22- Castellan CS, Luiz AC, Bezinelli LM, Lopes RM, Mendes FM, De P Eduardo $\mathrm{C}$, et al. In vitro evaluation of enamel demineralisation after Er:YAG and Nd:YAG laser irradiation on primary teeth. Photomed Laser Surg. 2007;25:85-90.
23- Chaussain-Miller C, Fioretti F, Goldberg M, Menashi S. The role of matrix metalloproteinases (MMPs) in human caries. J Dent Res. 2006;85:22-32.

24- Dawes $\mathrm{C}$. The effects of flow rate and duration of stimulation on the concentrations of protein and the main electrolytes in human parotid saliva. Arch Oral Biol. 1969;14:277-94.

25- Eisenburger M, Addy M. Evaluation of $\mathrm{pH}$ and erosion time on demineralisation. Clin Oral Investig. 2001;5:108-11.

26- Ganss C, Klimek J, Brune V, Schumann A. Effects of two fluoridation measures in erosion progression on enamel and dentin in situ. Caries Res. 2004;38:561-6.

27- Ganss C, Klimek J, Starck C. Quantitative analysis of the impact of the organic matrix on the fluoride effect on erosion progression in human dentine using longitudinal microradiography. Arch Oral Biol. 2004;49:931-5.

28- Ganss C, Lussi A, Klimek J. Comparison of calcium/phosphorus analysis, longitudinal microradiography and profilometry for the quantitative assessment of erosive demineralisation. Caries Res. 2005;39:178-84.

29- Ganss C, Lussi A. Diagnosis of tooth wear. Monogr Oral Sci. 2006;20:32-43

30- Ganss C, Schlueter N, Friedrich D, Klimek J. Retention of KOHsoluble fluoride on enamel and dentine under erosive conditions- A comparison of in vitro and in situ results. Arch Oral Biol. 2007;52:9-14.

31- Ganss C, Schlueter N, Friedrich D, Klimek J. Efficacy of waiting periods and topical fluoride treatment on toothbrush abrasion of eroded enamel in situ. Caries Res. 2007;41:146-51.

32- Ganss C, Schlueter N, Hardt M, Schattenberg P, Klimek J. Effect of fluoride compounds on enamel erosion in vitro: a comparison of amine, sodium and stannous fluoride. Caries Res. 2008;42:2-7.

33- Gedalia I, Dakuar A, Shapira L, Lewinstein I, Goultschin J, Rahamim E. Enamel softening with Coca-Cola and rehardening with milk or saliva. Am J Dent. 1991;4:120-2

34- Gendron R, Grenier D, Sorsa T, Mayrand D. Inhibition of the activities of matrix metalloproteinases 2, 8, and 9 by chlorhexidine. Clin Diag Lab Immunol. 1999;6:437-9.

35- Hall AF, Buchanan CA, Millett DT, Creanor SL, Strang R, Foye RH. The effect of saliva on enamel and dentine erosion. J Dent. 1999;27:333-

36- Hannig C, Hamkens A, Becker K, Attin R, Attin T. Erosive effects of different acids on bovine enamel: release of calcium and phosphate in vitro. Arch Oral Biol. 2005;50:541-52.

37- Hannig M, Balz M. Protective properties of salivary pellicles from two different intraoral sites on enamel erosion. Caries Res. 2001;35:1428 .

38- Hannig M, Fiebiger M, Güntzer M, Döbert A, Zimehl R, Nekrashevych Y. Protective effect of the in situ formed short-term salivary pellicle. Arch Oral Biol. 2004;49:903-10.

39- Hara AT, Lussi A, Zero DT. Biological Factors. Monogr Oral Sci 2006;20:88-99.

40- Hooper S, West NX, Pickles MJ, Joiner A, Newcombe RG, Addy M. Investigation of erosion and abrasion on enamel and dentine: a model in situ using toothpastes of different abrasivity. J Clin Periodontol. $2003 ; 30: 802-8$ 
41- Hove L, Holme B, Øgaard B, Willumsen T, Tveit AB. The protective effect of $\mathrm{TiF}_{4}, \mathrm{SnF}_{2}$ and $\mathrm{NaF}$ on erosion of enamel by hydrochloric acid in vitro measured by white light interferometry. Caries Res. 2006;40:440-3.

42- Hove LH, Young A, Tveit AB. An in vitro study on the effect of $\mathrm{TiF}_{4}$ treatment against erosion by hydrochloric acid on pellicle-covered enamel. Caries Res. 2007;41:80-4.

43- Hughes JA, Jandt KD, Baker N, Parker D, Newcombe RG, Eisenburger $\mathrm{M}$, et al. Further modification to soft drinks to minimise erosion. A study in situ. Caries Res. 2002;36:70-4.

44- Hunter ML, West NX, Hughes JA, Newcombe RG, Addy M. Erosion of deciduous and permanent dental hard tissue in the oral environment. $\mathrm{J}$ Dent. 2000;28:257-63

45- Ireland AJ, McGuinness N, Sherriff M. An investigation into the ability of soft drinks to adhere to enamel. Caries Res. 1995;29:470-6.

46- Jensdottir T, Nauntofte B, Buchwald C, Bardow A. Effects of sucking acidic candy on whole-mouth saliva composition. Caries Res. 2005;39:468-74

47- Joiner A, Schwarz A, Philpotts CJ, Cox TF, Huber K, Hannig M. The protective nature of pellicle towards toothpaste abrasion on enamel and dentine. J Dent. 2008;36:360-8

48- Kato MT, de Carvalho Sales-Peres SH, Buzalaf MA. Effect of iron on acid demineralisation of bovine enamel blocks by a soft drink. Arch Oral Biol. 2007;52:1109-11

49- Kato MT, Magalhães AC, Rios D, Attin T, Buzalaf MAR. The protective effect of green tea on dentin erosion and abrasion: an in situ study. Caries Res. 2008;42:188.

50- Kinney SH, Balooch M, Haript DL Jr, Marshall SJ, Marshall GW Jr. Mineral distribution and dimensional changes in human dentin during demineralisation. J Dent Res. 1995;74:1179-84.

51- Lagerweij MD, Buchalla W, Kohnke S, Becker K, Lennon AM, Attin $\mathrm{T}$. Prevention of erosion and abrasion by a high fluoride concentration gel applied at high frequencies. Caries Res. 2006;40:148-53.

52- Lan WH, Liu HC. Sealing of human dentinal tubules by Nd:YAG laser. J Clin Laser Med Surg. 1995;13:329-33.

53- Larsen MJ, Nyvad B. Enamel erosion by some soft drinks and orange juices relative to their $\mathrm{pH}$, buffering effect and contents of calcium phosphate. Caries Res. 1999;33:81-7.

54- Larsen MJ, Richards A. Fluoride is unable to reduce dental erosion from soft drinks. Caries Res. 2002;36:75-80.

55- Lennon AM, Pfeffer M, Buchalla W, Becker K, Lennon S, Attin T. Effect of a casein/calcium phosphate-containing tooth cream and fluoride on enamel erosion in vitro. Caries Res. 2006;40:154-7.

56- Lippert F, Parker DM, Jandt KD. Susceptibility of deciduous and permanent enamel to dietary acid-induced erosion studied with atomic force microscopy nanoindentation. Eur J Oral Sci. 2004;112:61-6.

57- Litonjua LA, Andreana S, Bush PJ, Cohen RE. Tooth wear: attrition, erosion, and abrasion. Quintessence Int. 2003;34:435-46

58- Lussi A, Jaeggi T, Schärer S. The influence of different factors on in vitro enamel erosion. Caries Res. 1993;27:387-93.

59- Lussi A, Jaeggi T, Zero D. The role of diet in the etiology of dental erosion. Caries Res. 2004;38:34-44.

60- Lussi A. Erosive tooth wear - a multifactorial condition of growing concern and increasing knowledge. Monogr Oral Sci. 2006;20:1-8.
61- Magalhães AC, Furlani TA, Italiani FM, Iano FG, Delbem AC, Buzalaf MA. Effect of calcium pre-rinse and fluoride dentifrice on remineralization of artificially demineralised enamel and on the composition of the dental biofilm formed in situ. Arch Oral Biol. 2007;52:1555-60.

62- Magalhães AC, Kato MT, Rios D, Wiegand A, Attin T, Buzalaf MAR. The effect of an experimental $4 \% \mathrm{TiF}_{4}$ varnish compared to $\mathrm{NaF}$ varnishes and $4 \% \mathrm{TiF}_{4}$ solution on dental erosion in vitro. Caries Res. 2008;42:26974.

63- Magalhães AC, Moraes SM, Rios D, Buzalaf MAR. The effect of ion supplementation of a commercial soft drink on tooth enamel erosion. Foods Addit Contam. In press 2009.

64- Magalhães AC, Rios D, Delbem AC, Buzalaf MA, Machado MA. Influence of fluoride dentifrice on brushing abrasion of eroded human enamel: an in situ/ex vivo study. Caries Res. 2007;41:77-9

65- Magalhães AC, Rios D, Honório HM, Jorge AM Jr, Delbem ACB, Buzalaf MAR. Effect of 4\% titanium tetrafluoride solution on dental erosion by a soft drink: an in situ/ex vivo study. Arch Oral Biol. 2008:53:399-404.

66- Magalhães AC, Rios D, Machado MAAM, Silva SMB, Lizarelli RFZ, Bagnato VS, et al. Effect of Nd:YAG irradiation and fluoride application on dentin resistance to erosion in vitro. Photomed Laser Surg. In press 2008

67- Magalhães AC, Rios D, Moino AL, Wiegand A, Attin T, Buzalaf MAR. Effect of different concentrations of fluoride in dentifrices on dentin erosion subjected or not to abrasion in situ/ex vivo. Caries Res. 2008;42:112-6

68- Mäkinen KK, Söderling E. Solubility of calcium salts, enamel and hydroxyapatite in aqueous solution of simple carbohydrates. Calcif Tissue Int. 1984,36:64-71

69- Meurman JH, Frank RM. Scanning electron microscope of the effect of salivary pellicle on enamel erosion. Caries Res. 1991;25:1-6.

70- Meyer-Lueckel H, Kielbassa AM. Use of saliva substitutes in patients with xerostomia. Schweiz Monatschr Zahnmed 2002;112:1037-58.

71- Meyer-Lueckel H, Tschoppe P, Kielbassa AM. Effect of various Ca2+/ PO4(3-) concentrations of linseed-based saliva substitutes on enamel in vitro. J Oral Rehabil. 2006;33:760-6.

72- Mundorff SA, Little MF, Bibby BG. Enamel dissolution. 2. Action of titanium tetrafluoride. J Dent Res. 1972;51:1567-71.

73- Naylor FV, Aranha ACC, Eduardo CP, Arana-Chavez VE, Sobral MAP. Micromorphological analysis of dentinal structure after irradiation with Nd:YAG laser and immersion in acidic beverages. Photomed Laser Surg. 2006;24:745-53.

74- Nelson DGA, Wefel JS, Jongebloed WL, Featherstone JDB. Morphology, histology and crystallography of human dental enamel treated with pulsed low-energy infrared laser radiation. Caries Res. 1987;21:41126.

75- O’Sullivan EA, Curzon MEJ. Salivary factors affecting dental erosion in children. Caries Res. 2000;34:82-7.

76- Pessan JP, Sicca CM, de Souza TS, da Silva SMB, Whitford GM, Buzalaf MAR. Fluoride concentrations in dental plaque and saliva after the use of a fluoride dentifrice preceded by a calcium lactate rinse. Eur J Oral Sci. 2006,114:489-93.

77- Piekarz C, Ranjitkar S, Hunt D, McIntyre J. An in vitro assessment of the role of Tooth Mousse in preventing wine erosion. Aust Dent J. 2008;53:22-5. 
78- Ponduri S, Macdonald E, Addy M. A study in vitro of the combined effects of soft drinks and tooth brushing with fluoride toothpaste on the wear of dentine. Int J Dent Hyg. 2005;3:7-12.

79- Rees J, Loyn T, Chadwick B. Pronamel and tooth mousse: An initial assessment of erosion prevention in vitro. J Dent. 2007;35:355-7.

80- Reynolds JJ, Meikle MC. The functional balance of metalloproteinases and inhibitors in tissue degradation: relevance to oral pathologies. J R Coll Surg Edinb. 1997;42:154-60.

81- Ribeiro CC, Gibson I, Barbosa MA. The uptake of titanium ions by hydroxiapatite particles - structural changes and possible mechanisms. Biomaterials. 2006;27:1749-61.

82- Rios D, Honório HM, Magalhães AC, Buzalaf MA, Palma-Dibb RG Machado MA, et al. Influence of toothbrushing on enamel softening and abrasive wear of eroded bovine enamel: an in situ study. Braz Oral Res. 2006;20:148-54

83- Rios D, Honório HM, Magalhães AC, Delbem ACB, Machado MAAM, Silva SMB, et al. Effect of salivary stimulation on erosion of human and bovine enamel subjected or not to subsequent abrasion: an in situ/ ex vivo study. Caries Res. 2006;40:218-23.

84- Rios D, Magalhães AC, Polo ROB, Wiegand A, Attin T, Buzalaf MAR. Efficacy of high dosage fluoride dentifrice on enamel erosion subjected or not to abrasion in situ/ex vivo. J Am Dent Assoc. 2008;139:1652-6.

85- Sales-Peres SH, Pessan JP, Buzalaf MAR. Effect of an iron mouthrinse on enamel and dentin erosion subjected or not to abrasion: an in situ/ ex vivo study. Arch Oral Biol. 2007;52:128-32.

86- Saxegaard E, Rolla G. Fluoride acquisition on and in human enamel during topical application in vitro. Scand J Dent Res. 1988;96:523-35.

87- Schlueter N, Ganss C, Mueller U, Klimek J. Effect of titanium tetrafluoride and sodium fluoride on erosion progression in enamel and dentine in vitro. Caries Res. 2007;41:141-5.

88- ten Cate JM. Review on fluoride, with special emphasis on calcium fluoride mechanisms in caries prevention. Eur J Oral Sci. 1997;105:4615 .

89- Tjaderhane L, Larjava H, Sorsa T, Uitto VJ, Larmas M, Salo T. The activation and function of host matrix metalloproteinases in dentin matrix breakdown in caries lesions. J Dent Res. 1998;77:1622-9.

90- Tsai CL, Lin YT, Huang ST, Chang H-W. In vitro acid resistance of $\mathrm{CO}_{2}$ and $\mathrm{Nd}$ :YAG laser - treated human tooth enamel. Caries Res. 2002;36:423-9.

91- Vieira A, Overweg E, Ruben JL, Huysmans MC. Toothbrush abrasion, simulated tongue friction and attrition of eroded bovine enamel in vitro. J Dent. 2006;34:336-42.

92- Vieira A, Ruben JL, Huysmans MC. Effect of titanium tetrafluoride, amine fluoride and fluoride varnish on enamel erosion in vitro. Caries Res. 2005;39:371-9.

93- Vogel GL, Chow LC, Carey CM, Schumacher GE, Takagi S. Effect of a calcium prerinse on salivary fluoride after a $228 \mathrm{ppm}$ fluoride rinse. Caries Res. 2006;40:178-80.

94- West NX, Hughes JA, Addy M. Erosion of dentine and enamel in vitro by dietary acids: the effect of temperature, acid character, concentration and exposure time. J Oral Rehabil. 2000;27:875-80.

95- Wiegand A, Attin T. Influence of fluoride on the prevention of erosive lesions - a review. Oral Health Prev Dent. 2003;1:245-53.

96- Wiegand A, Attin T. Occupational dental erosion from exposure to acids: a review. Occup Med (Lond). 2007;57:169-76.
97- Wiegand A, Begic M, Attin T. In vitro evaluation of abrasion of eroded enamel by different manual, power and sonic toothbrushes. Caries Res. 2006;40:60-5.

98- Wiegand A, Egert S, Attin T. Toothbrushing before or after an acidic challenge to minimize tooth wear? An in situ/ex vivo study. Am J Dent. 2008;21:13-6.

99- Wiegand A, Köwing L, Attin T. Impact of brushing force on abrasion of acid-softened and sound enamel. Arch Oral Biol. 2007;52:1043-7.

100- Wiegand A, Laabs KA, Gressmann G, Roos M, Magalhães AC, Attin T. Protection of short-time enamel erosion by different tetrafluoride compounds. Arch Oral Biol. 2008;53:497-502.

101- Wiegand A, Lemmrich F, Attin T. Influence of rotating-oscillating, sonic and ultrasonic action of power toothbrushes on abrasion of sound and eroded dentine. J Periodontal Res. 2006;41:221-7.

102- Wiegand A, Meier W, Sutter E, Magalhães AC, Becker K, Roos M, et al. Protective effect of different tetrafluorides on erosion of pelliclefree and pellicle-covered enamel and dentin. Caries Res. 2008;42:24754.

103- Wiegand A, Schwerzmann M, Sener B, Magalhães AC, Roos M, Ziebolz D, et al. Impact of toothpaste slurry abrasivity and toothbrush filament stiffness on abrasion of eroded enamel - an in vitro study. Acta Odontol Scand. 2008;66:231-6

104- Wiegand A, Stock A, Attin R, Werner C, Attin T. Impact of the acid flow rate on dentin erosion. J Dent. 2007;35:21-7.

105- Wiegand A, Wolmershäuser S, Hellwig E, Attin T. Influence of buffering effects of dentifrices and fluoride gels on abrasion on eroded dentine. Arch Oral Biol. 2004;49:259-65.

106-Zero DT, Lussi A. Behavioral factors. Monogr Oral Sci. 2006;20:100- 